\title{
The Metabolism of Iron-, Zinc- and Manganese- Deficient Nocardia opaca
}

\author{
By D. M. WEBLEY, R. B. DUFF AND G. ANDERSON \\ The Macaulay Institute for Soil Research, Aberdeen
}

(Received 27 December 1961)

\begin{abstract}
SUMMARY
The metabolism of iron-, zinc- and manganese-deficient cells of $N$. opaca was studied. Zinc-deficient organism showed inability to utilize reserve carbohydrate as compared with organism grown under normal conditions. Manganese deficiency caused a much decreased DNA synthesis. Iron deficient organism lacked catalase and the oxygen uptake with certain substrates (pyruvate, phenylacetate, $n$-dodecane) was markedly affected.
\end{abstract}

\section{INTRODUCTION}

In a previous paper (Webley, 1960) it was shown that iron-, zinc- and manganese were required for optimum growth of Nocardia opaca and that deficiency of manganese caused marked morphological changes in the organism, irrespective of the substrate on which it was grown. In the present work a study of organisms deficient in these trace elements revealed several differences in their chemical composition and metabolism as compared with organisms grown on complete medium.

\section{METHODS}

Organism. Nocardia opaca strain T 16 described previously (Webley,1954) was used.

Production of metal-deficient organisms. Details about the treatment of glassware, and the composition and preparation of media for individual deficiencies were given in a previous paper (Webley, 1960). After growth no special precautions in the harvesting of the organisms were necessary.

Manometry. Carried out by the conventional Warburg techniques at $25^{\circ}$.

Fractionation of the cell material. The Mickle disintegrator (Mickle, 1948) was used to break organisms, in suspensions containing 10-20 mg. dry wt. organism/ml., with ballotini beads (no. 12) for 15-20 min. The Vibrogen cell mill (E. Bühler, Tübingen, Germany) was used when large volumes $(100 \mathrm{ml}$.) of suspension were to be broken. After removal of the glass beads the broken preparations were centrifuged at $35,000 \mathrm{~g}$ in a refrigerated centrifuge. The debris was washed twice with distilled water at $35,000 \mathrm{~g}$ and proved, on examination with the electron microscope, to be principally cell-wall material with some amorphous material. The cell-free extracts and debris were used directly or were freeze-dried, as required.

Carbohydrate determinations. Usually descending chromatograms were run in butan-1-ol + acetic acid+ water $(4+1+5$, by vol.) on Whatman no. 1 paper with aniline phthalate or benzidine + trichloroacetic acid (Bacon \& Edelman, 1951) as a spray for revealing sugars. The anthrone method of Fairbairn (1953) was used for 
the estimation of total carbohydrate. The results were calculated in terms of glucose although paper chromatography showed that other sugars (particularly arabinose) were present in the hydrolysates of whole organisms. Therefore the results can only be regarded as comparative. Estimations on the paper chromatograms were done as described by Duff \& Eastwood (1950).

Lipid determinations. The method of Reichert (1944) was used; the organisms were treated with boiling methanol and then extracted with diethyl ether (after removal of methanol). An apparatus was adapted for extracting smaller amounts of material (equiv. $50 \mathrm{mg}$. dry wt.) than required in the original method; two extractions were made.

Nucleic acid determinations. The freeze-dried cell contents were separated into fractions containing RNA and DNA as described by Elson, Gustafson \& Chargaff (1954). The sediment containing the DNA fraction was hydrolysed with $12 \mathrm{~N}$ perchloric acid (Marshak \& Vogel, 1951). The solution containing nucleotides derived from RNA was evaporated to dryness in vacuo at $20^{\circ}$, taken up in N-hydrochloric acid and hydrolysed at $100^{\circ}$ for $1 \mathrm{hr}$. (Markham \& Smith, 1951). The purine and pyrimidine bases obtained from DNA were chromatographed in two dimensions on Whatman no. 1 paper: $(a)$ upwards in isopropanol+hydrochloric acid+water (Wyatt, 1951); (b) downwards in $n$-butanol + ammonia + water (MacNutt, 1952). The mixture of purine bases and pyrimidine nucleotides from the RNA was chromatographed upwards in isopropanol+hydrochloric acid+water. Bases and nucleotides were detected under u.v. radiation, eluted with $0.1 \mathrm{~N}-\mathrm{HCl}$ and estimated spectrophotometrically, using extinction coefficients quoted by Markham \& Smith (1951) and Wyatt (1951).

\title{
RESULTS
}

\section{Chemical analysis of metal-deficient organisms}

From Table 1 it can be seen that, whereas the total nitrogen contents of the complete and $\mathrm{Mn}$ deficient organisms were very similar, the $\mathrm{Zn}$ - and Fe-deficient cells had, respectively, lower and higher total nitrogen contents. The explanation of

Table 1. Chemical analysis of Nocardia opaca grown in complete medium or in $\mathrm{Fe}$-, $\mathrm{Mn}$ - or $\mathrm{Zn}$-deficient medium

\begin{abstract}
N. opaca grown in $200 \mathrm{ml}$. complete medium or in Fe-, $\mathrm{Mn}$ - or $\mathrm{Zn}$-deficient medium with $20 \mathrm{~g}$. glucose $/ 1$. on a shaker at $25^{\circ}$. Organisms harvested after 7 days and washed 3 times with double-distilled water and made up to known volume. A sample of the washed suspension was used for determination of total nitrogen, carbohydrate and lipid content. The figures given as \% of the dry wt. of the cell suspension.
\end{abstract}

\begin{tabular}{|c|c|c|c|}
\hline & Total nitrogen & $\begin{array}{l}\text { Carbohydrate } \\
\text { (as glucose) }\end{array}$ & Lipid \\
\hline & $\mathrm{mg} \cdot / 1$ & mg. dry wt. or & \\
\hline Complete & $7 \cdot 97$ & $13 \cdot 4$ & $13 \cdot 9$ \\
\hline$-\mathbf{F e}$ & 11.90 & 4.5 & - \\
\hline$-\mathbf{M n}$ & $7 \cdot 65$ & $11 \cdot 5$ & $13 \cdot 1$ \\
\hline$-\mathbf{Z n}$ & $5 \cdot 17$ & $\mathbf{3 9 \cdot 3}$ & $10 \cdot 60$ \\
\hline
\end{tabular}

these differences is more clearly understood on examination of the carbohydrate figures. These show that the $\mathrm{Zn}$-deficient organisms had a much higher carbohydrate content than the complete and Mn-deficient organisms while the Fe- 
deficient organisms were much lower in carbohydrate. Similarly, when grown on other substrates (sucrose, glycerol, phenylacetate, acetate), the $\mathrm{Zn}$-deficient organisms always had the highest carbohydrate content. Irrespective of growth conditions, when organisms were hydrolysed for $4 \mathrm{hr}$. at $100^{\circ}$, paper chromatography showed glucose and arabinose in all organisms. The glucose spot was much more intense in the hydrolysate of the $\mathrm{Zn}$-deficient organisms than in the others. The lipid content of the $\mathrm{Zn}$-deficient organisms was slightly less than that of the complete or Mn-deficient organisms. The equipment used did not permit the production of sufficient Fe-deficient organisms for their lipid content to be determined.

\section{Table 2. Carbohydrate content of Nocardia opaca during growth on $\mathrm{Z}$-deficient medium}

N. opaca grown in $200 \mathrm{ml}$. complete medium, or $\mathrm{Zn}$-deficient medium with $20 \mathrm{~g}$. glucose/l. on a shaker at $25^{\circ}$. Samples 5-10 ml. periodically removed aseptically and centrifuged. Organisms washed twice with distilled water and suspended in $2 \cdot 0 \mathrm{ml}$. water. Carbohydrate analysis (anthrone reaction) on samples of suspension and supernatant fluid of original sample.

\begin{tabular}{|c|c|c|c|c|}
\hline \multirow[b]{2}{*}{ Days } & \multicolumn{2}{|c|}{ Complete-medium organisms } & \multicolumn{2}{|c|}{ Zn-deficient organisms } \\
\hline & $\begin{array}{c}\text { Residual } \\
\text { glucose in } \\
\text { medium } \\
(\mathrm{mg} \cdot / \mathrm{ml} .)\end{array}$ & $\begin{array}{c}\text { Carbohydrate } \\
\text { in organism } \\
\text { (mg./100 mg. } \\
\text { dry wt.) }\end{array}$ & $\begin{array}{c}\text { Residual } \\
\text { glucose in } \\
\text { medium } \\
\text { (mg./ml.) }\end{array}$ & $\begin{array}{c}\text { Carbohydrate } \\
\text { in organism } \\
\text { (mg./100 mg. } \\
\text { dry wt.) }\end{array}$ \\
\hline 4 & 14.7 & $9 \cdot 8$ & $12 \cdot 5$ & $15 \cdot 2$ \\
\hline 5 & $4 \cdot 6$ & $15 \cdot 6$ & $12 \cdot 25$ & $\mathbf{3 1} \cdot \mathbf{5}$ \\
\hline 6 & $1 \cdot 15$ & $\mathbf{3 4} \cdot 9$ & $9 \cdot 0$ & $35 \cdot 7$ \\
\hline 7 & 0.28 & $5 \cdot 5$ & 6.0 & 24-8 \\
\hline 8 & 031 & - & $4 \cdot 05$ & $32 \cdot 5$ \\
\hline $\mathbf{9}$ & Nil & $6 \cdot 6$ & $\mathbf{2 \cdot 0}$ & $26 \cdot 4$ \\
\hline 11 & Nil & $8 \cdot 3$ & Nil & $12 \cdot 0$ \\
\hline
\end{tabular}

\section{Effect of zinc deficiency on carbohydrate content of organisms}

In view of the greater carbohydrate content of $\mathrm{Zn}$-deficient organisms grown on all substrates tested, an experiment was set up to follow the carbohydrate content of the organisms during growth under these conditions. For this two 1 l. culture flasks (Jobling Cat. no. 1410) each containing $200 \mathrm{ml}$. of medium, one complete and the other $\mathrm{Zn}$-deficient, were set up. At intervals 5-10 ml. samples were removed. The organisms were centrifuged, well washed and finally suspended in $2 \mathrm{ml}$. distilled water. A sample was removed from each suspension for determination of dry weight and for carbohydrate content (Table 2). In the complete-medium-grown organisms the carbohydrate content decreased rapidly after reaching its maximum, whereas in the $\mathrm{Zn}$-deficient organisms it did not. The decrease in the carbohydrate content of the complete-medium organisms took place when the glucose had been almost exhausted. It appears that reserve carbohydrates are affected by zinc deficiency.

The polysaccharide material in the complete and $\mathrm{Zn}$-deficient organisms was extracted by the procedure of Palmstierna (1956). The moisture content of a sample of wet organism was estimated and the necessary amounts of $\mathrm{KOH}$ and water added to give $300 \mathrm{~g}$. $/ 1$. solution of $\mathrm{KOH}$. This was heated at $100^{\circ}$ for $3 \mathrm{hr}$. After mixing with water, the solution was poured into ethanol and the precipitated crude glycogen dialysed in aqueous solution. The polysaccharide was recovered by pouring the 
dialysed solution, after evaporation in vacuo, into ethanol. The crude polysaccharide was purified by reprecipitation from water with glacial acetic acid. The yield was $24 \%$ of the dry weight of $\mathrm{Zn}$-deficient organisms and $14 \%$ of the dry weight of complete-medium grown organisms. Both specimens gave glucose, together with small amounts of mannose and arabinose, after hydrolysis and chromatography in the usual way. Paper chromatographic analyses of hydrolysates of the cell fractions were also carried out (Table 3). All the arabinose and most of the glucose was associated with the cell debris.

Table 3. Paper chromatographic analysis of sugars in cell debris and cell-free extract from complete and $\mathrm{Z} n$-deficient Nocardia opaca

$N$. opaca grown in $200 \mathrm{ml}$. complete medium or $\mathrm{Zn}$-deficient medium with $20 \mathrm{~g}$. glucose/1. on a shaker at $25^{\circ}$. Organisms harvested after 6 days, washed 3 times with double-distilled water. Suspensions (equiv. 10-20 mg. dry wt. ml.) disintegrated and centrifuged at $35,000 \mathrm{~g}$. Cell debris and cell-free extract freeze-dried. Freeze-dried fractions hydrolysed with $\mathrm{N}-\mathrm{H}_{2} \mathrm{SO}_{4}$ at $100^{\circ}$ for $\mathrm{5} \mathrm{hr}$. in sealed tubes and analysed for sugars after chromatographic separation as described in Methods. The results are the average of two determinations.

Organisms grown on

\begin{tabular}{|c|c|c|c|}
\hline \multicolumn{2}{|c|}{ Complete-medium } & \multicolumn{2}{|c|}{ Zn-deficient medium } \\
\hline Cell debris & Cell-free extract & Cell-debris & Cell-free extrac \\
\hline \multicolumn{4}{|c|}{ Sugar (mg./100 mg. dry wt. preparation) } \\
\hline $4.0(8 \cdot 2)^{*}$ & $7 \cdot 6(5 \cdot 2)$ & $21 \cdot 7(14 \cdot 4)$ & $5 \cdot 7(5 \cdot 0)$ \\
\hline $12 \cdot 6(10 \cdot 1)$ & Nil (Nil) & $12 \cdot 3(10 \cdot 5)$ & Nil (Nil) \\
\hline Trace $(2 \cdot 4)$ & $3 \cdot 4(4 \cdot 1)$ & Trace $(2 \cdot 6)$ & $1 \cdot 6(4 \cdot 1)$ \\
\hline Nil (Nil) & $0.6(2 \cdot 0)$ & Nil (Nil) & $2.7(3.8)$ \\
\hline
\end{tabular}

* The results of a second experiment with a different batch of organisms are given in parentheses.

Nature of the carbohydrate in the cell-free extract. The crude polysaccharide from Zn-deficient organisms was fractionated by the Cetavlon procedure of German, Jones \& Nadarajah (1961). From the major fractions at $\mathrm{pH} 7 \cdot 5$ and $9 \cdot 5$. Cetavlon was removed with $2 \mathrm{~N}$ acetic acid and the recovered glycogen reprecipitated from aqueous solution with glacial acetic acid. Both samples gave infrared absorption peaks at 930,845 and $758 \mathrm{~m} \mu$, as obtained for glycogen by the above authors. Hydrolysis with $\mathrm{N}_{-} \mathrm{H}_{2} \mathrm{SO}_{4}$ at $100^{\circ}$ for $5 \mathrm{hr}$. and subsequent paper chromatography showed that glucose was the main constituent, accompanied by a small amount of ribose (from nucleic acid), and mannose, in the $\mathrm{pH} 7.5$ and 9.5 fractions, respectively.

The fractions were combined for optical rotation determination, the mixture had $[\alpha]_{\mathrm{D}}+165^{\circ}$ (conc. $5 \mathrm{~g}$./l. of aqueous solution). The glycogen isolated gave a brown colour with iodine, having a maximum u.v. absorption at $360 \mathrm{~m} \mu$, E360 1.07 (an appropriate value due to light scattering). In these experiments we used a $8 \mathrm{~g} . / \mathrm{l}$. aqueous solution of glycogen $(1.56 \mathrm{ml})+.1.60 \mathrm{ml}$. saturated ammonium sulphate + $0.08 \mathrm{ml}$. potassium trio-idide solution $(1.25 \mathrm{~g}$. $/ \mathrm{l}$. I in $2.5 \mathrm{~g} . / \mathrm{l} . \mathrm{KL})$, the conditions are comparable to those used by Schlamowitz (1951). 


\section{Effect of trace element deficiency on $R N A$ and $D N A$ content of Nocardia opaca}

Webley (1960) showed that Mn deficiency caused marked morphological effects during the growth of Nocardia opaca. The organisms did not fragment in the usual way but continued to grow in the mycelial phase. As the cultures became older, bulbous swellings frequently appeared on the filaments. Amino acid analysis (DeKock \& Morrison, 1958) of cell debris from complete, $\mathrm{Zn}$ - and Mn-deficient organisms showed the following: aspartic acid, glutamic acid, serine, $\alpha$-alanine, valine, leucine, glucosamine, diaminopimelic acid, muramic acid. Muramic acid has been associated only with bacterial cell walls (Strange, 1956; Work, 1957). The acid was present in the cell debris from complete, $\mathrm{Zn}$ - and Mn-deficient organisms in the ratio $1 \cdot 4: 1 \cdot 3: 1 \cdot 0$, respectively.

Table 4. RNA compositions of freeze-dried cell-free extracts from Nocardia opaca grown in complete medium or $\mathrm{Zn}$ - or $\mathrm{Mn}$-deficient medium

$N$. opaca grown in $200 \mathrm{ml}$. complete medium or $\mathrm{Zn}$ - or $\mathrm{Mn}$-deficient medium with $20 \mathrm{~g}$. glucose/l. on a shaker at $25^{\circ}$. Organisms harvested after 6 days and washed 3 times with double-distilled water. Cell suspensions (10-20 mg./dry wt. ml.) disintegrated and centrifuged at $35,000 \mathrm{~g}$. Cell-free extract freeze-dried. Purine bases and pyrimidine nucleotides obtained from the RNA fraction and estimated as described in Methods.

\begin{tabular}{|c|c|c|c|}
\hline & \multicolumn{3}{|c|}{ Organisms from media } \\
\hline & Complete & Zn-deficient & Mn-deficient \\
\hline & \multicolumn{3}{|c|}{ Base proportions (moles \%) } \\
\hline Guanine (G) & $33 \cdot 0^{*}$ & $\mathbf{3 2 \cdot 1}$ & $\mathbf{3 0 \cdot 1}$ \\
\hline Adenine (A) & $23 \cdot 0$ & $23 \cdot 8$ & $\mathbf{2 2 \cdot 2}$ \\
\hline Cystosine (C) & $23 \cdot 8$ & $24 \cdot 6$ & $\mathbf{2 5} \cdot 4$ \\
\hline Uracil (U) & $20 \cdot 2$ & $19 \cdot 6$ & $22 \cdot 2$ \\
\hline Purines/pyrimidines & $\mathbf{1 \cdot 2 7}$ & $1 \cdot 26$ & $\mathbf{1 \cdot 1 0}$ \\
\hline $\mathbf{G}+\mathbf{U} / \mathbf{A}+\mathbf{C}$ & $1 \cdot 14$ & 1.07 & $1 \cdot 10$ \\
\hline
\end{tabular}

* Values are the means of at least two chromatographic analyses of hydrolysis products.

Table 5. DNA composition of freeze-dried cell-free extract from Nocardia opaca grown in complete medium or in $\mathrm{Z} n$-deficient medium

$N$. opaca grown in $200 \mathrm{ml}$. complete medium or in $\mathrm{Zn}$ - or $\mathrm{Mn}$-deficient medium with $20 \mathrm{~g}$. glucose/1. on a shaker at $\mathbf{2 5}^{\circ}$. Organisms harvested after 6 days and washed 3 times with double-distilled water. Suspensions (equiv. $10-20 \mathrm{mg} . / \mathrm{ml}$. dry wt.) disintegrated and centrifuged at $35,000 \mathrm{~g}$. Cell-free extract freeze-dried. Purine and pyrimidine bases obtained from DNA fraction as described in Methods.

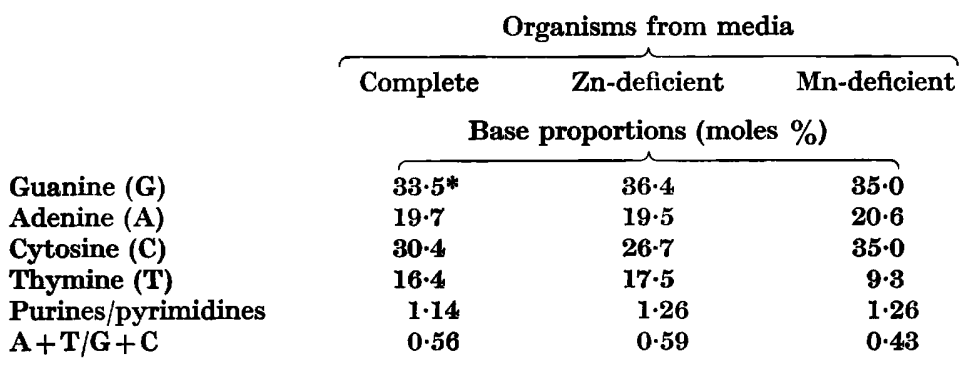

* Values the means of two chromatographic analyses of hydrolysis products. 
Hydrolysis of the cell debris with perchloric acid gave only traces of purine and pyrimidine bases on paper chromatograms (see Table 3), no ribose was contained in this fraction.

The relative proportions of the bases in the RNA and DNA fractions from freezedried cell-free extract are shown in Tables 4 and 5. The composition of the RNA was similar for the differently grown organisms. The DNA was similar in the complete and $\mathrm{Zn}$-deficient organisms but the recovery of pyrimidines appears to be slightly low in both cases. The amounts of bases in the Mn-deficient organisms were so low that only approximate values could be obtained. To confirm the deficiency of thymine relative to adenine in the DNA, large-scale fractionation and isolation would be necessary. The nucleic acid contents of the cell-free extracts are given in Table 6. The absolute amounts of DNA and the ratio of DNA to RNA were lower in the Mn-deficient organisms.

Table 6. Nucleic acid content of cell-free extracts from Nocardia opaca grown in complete medium or $\mathrm{Z} n$ - or $\mathrm{M} n$-deficient medium

Values calculated from analysis of the amounts of bases and nucleotides obtained by hydrolysis of DNA and RNA fractions.

\begin{tabular}{llll} 
& \multicolumn{2}{c}{ Organisms grown in media } \\
& $\overbrace{\begin{array}{c}\text { Complete } \\
\text { mg./100 mg. freeze-dried preparation }\end{array}}^{\text {Zn-deficient }} \begin{array}{c}\text { Mn-deficient } \\
\text { DNA }\end{array}$ & $\overbrace{3.41(2.97)}^{1.96}$ & $1.43(1.09)$ \\
RNA & $\mathbf{3 . 4 6 ( 1 . 9 8 )}$ & 1.97 & $2.45(4.75)$ \\
DNA/RNA & $0.99(1.50)$ & 0.99 & $0.58(0.23)$
\end{tabular}

The results for a second batch of organisms given in parentheses. The second Mn-deficient batch was harvested after 10 days, the others after 6 days.

Warburg experiments with trace element deficient organisms of Nocardia opaca

Catalase activity. Table 7 shows that Fe-deficient organisms lacked catalase activity. A similar result was reported for Aerobacter aerogenes by Waring \& Werk$\operatorname{man}(1944)$.

Oxidation of added substrates. Table 8 shows that the oxidation of glucose by Fe-deficient organisms was not nearly so much affected as was that of other substrates. A similar result was obtained by Waring \& Werkman (1944) with irondeficient Aerobacter aerogenes. The marked effect on pyruvic oxidation suggested that this acid might accumulate in iron-deficient cultures. Iron-deficient growth experiments were set up with glucose, gluconate, sucrose or glycerol as substrates. After growth for 7 days a strong reaction for pyruvic acid was obtained with the Rothera test when applied to the supernatant fluid after removal of organisms by centrifugation. Similar tests on the supernatant fluids from complete, $\mathrm{Zn}$ - and Mn-deficient cultures gave negative results. Further confirmation of the presence of pyruvic acid in Fe-deficient cultures was obtained as follows. 2:4-Dinitrophenylhydrazine in $2 \mathrm{~N}-\mathrm{HCl}$ was added to a suitable sample of the supernatant fluid from an Fe-deficient culture in which glucose was the substrate. The precipitated hydrazone, when examined by infrared analysis, was identical with the hydrazone prepared from pure pyruvic acid. No similar pyruvic acid derivative was obtained 
from corresponding supernatant fluids of organisms grown on complete medium, Zn- or Mn-deficient media.

The oxygen uptakes of $\mathrm{Zn}$ - or Mn-deficient organisms in the presence of the substrates used by complete and Fe-deficient organisms (Table 8) were generally inferior to those of complete organisms. But the results were too variable to draw conclusion about effects on specific substrates. Addition of the respective trace elements to the Warburg vessels in a form and concentration similar to those used for the complete medium in the growth experiments did not affect the oxygen uptake.

\section{Table 7. Catalase activity of trace element-deficient Nocardia opaca}

Organisms grown in complete medium or in Fe-, Mn- or Zn-deficient medium containing 20 g. glucose/l. Harvested washed, and suspended in double-distilled water (equiv. $10 \mathrm{mg}$. dry wt./ml.). In main compartment of Warburg vessel $0.1 \mathrm{ml}$. suspension $+0.5 \mathrm{ml}$. $\mathrm{M} / 15$ buffer $\left(\mathrm{pH} \mathrm{7 \cdot 2}\right.$ ) and distilled water to give $2.5 \mathrm{ml}$. In side arm $0.2 \mathrm{ml} . \mathrm{H}_{2} \mathrm{O}_{2}$ (3 g./l.). $\mathrm{H}_{2} \mathrm{O}_{2}$ tipped after 15 min. equilibrium time.

$\begin{array}{lc} & \begin{array}{c}\mathrm{O}_{2} \text { output } \\ \text { in 3 min. }\end{array} \\ \text { Medium } & (\mu \mathrm{l} .) \\ \text { Complete } & \mathbf{5 7 \cdot 0} \\ \text { Fe-deficient } & \mathbf{2 \cdot 1} \\ \text { Mn-deficient } & \mathbf{5 9 \cdot 0} \\ \text { Zn-deficient } & 54 \cdot 0\end{array}$

Table 8. Oxidation of various substrates by Fe-deficient Nocardia opaca

N. opaca grown in complete medium or in Fe-deficient medium containing $20 \mathrm{~g}$. glucose/1. After 7 days cells harvested and washed twice and suspended in doubledistilled water to contain equiv. 10-12 mg. dry wt. organism/ml. In Warburg vessels $1.0 \mathrm{ml}$. suspension $+0.5 \mathrm{ml}$. $\mathrm{M} / 15 \mathrm{buffer}(\mathrm{pH} 7 \cdot 2)+0.5 \mathrm{ml} . \mathrm{M} / 50$ substrate and distilled water to give $2.5 \mathrm{ml}$.

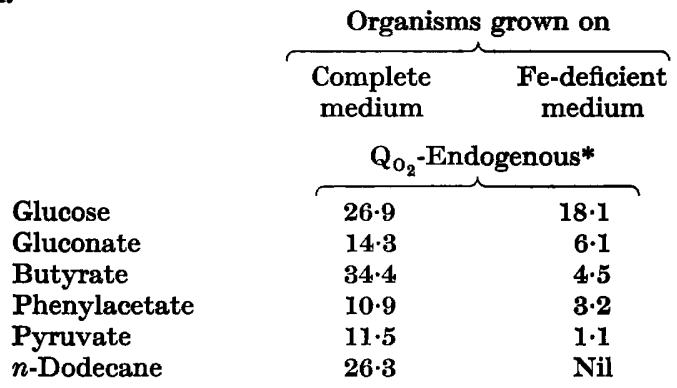

* Endogenous $Q_{\mathrm{O}_{2}}$ was $9 \cdot 12$ and 5.3 for complete medium grown organisms and Fe-deficient medium grown organisms, respectively.

\section{DISCUSSION}

The results recorded in Table 2 suggest that $\mathrm{Zn}$-deficient Nocardia opaca is unable to utilize its reserve polysaccharide as rapidly as organisms grown in the complete medium. Stein \& Fischer (1960) showed that crystalline $\alpha$-amylase from Bacillus subtilis is a zinc protein complex. Perhaps the polysaccharide splitting enzyme in $N$. opaca is also dependent on zinc.

The effect of manganese deficiency on DNA synthesis by Nocardia opaca is 
interesting in the light of previous work (Webley, 1960) on the morphology of this organism when grown in Mn-deficient medium. It is well established that in normal growth the DNA content increases before cell division (Belozersky \& Spirin, 1960). Jeener \& Jeener (1952) showed that the deoxyribonucleoside-dependent Thermobacterium acidophilis $\mathbf{R ~ 2 6}$, when cultured in the absence of DNA, produced elongated cells which did not divide. In the light of these observations it is reasonable to suggest that when $N$. opaca is cultured under conditions of Mn deficiency the production of filamentous forms is caused by failure of normal DNA synthesis.

The presence of pyruvic acid in Fe-deficient cultures suggests that the pyruvic oxidase of the organism may be iron dependent. O'Kane (1954) showed that the pyruvate oxidase of Clostridium butyricum required ferrous ion.

We are indebted to the following members of the Macaulay Institute staff: Dr V. C. Farmer for ultraviolet and infrared analyses; Mr W. Bick for nitrogen determinations and paper chromatographic analysis of amino acids, $\mathbf{M r}$ M. Davidson, Miss B. D. Milne, Mrs S. M. Lindsay and Miss M. L. Coutts for technical assistance. We are grateful to $\mathrm{Mr}$ W. Hodgkiss of the Torry Research Station, Aberdeen, for examining the disintegrated organisms under the electron microscope.

\section{REFERENCES}

Bacon, J. S. D. \& Edelman, J. (1951). The carbohydrates of the Jerusalem artichoke and other Compositae. Biochem. J. 48, 114.

Belozersky, A. N. \& Spirin, A. S. (1960). Chapter 32 in vol. 3 of The Nucleic Acids, by Chargaff, E. \& Davidson, J. N. New York: Academic Press Inc.

DeKock, P. C. \& Morrison, R. I. (1958). Metabolism of chlorotic leaves. The amino acids. Biochem. J. 70, 266.

DUFF, R. B. \& EASTwood, D. J. (1950). Use of the arsenomolybdate-Somogyi reagent in quantitative paper chromatography and its application to the study of sucrose utilisation by a fungus. Nature, Lond. 165, 848 .

Elson, D., Gustafson, T. \& Chargaff, E. (1954). The nucleic acids of the sea-urchin during embryonic development. J. biol. Chem. 209, 285.

Fairburn, N. J. (1953). A modified anthrone reagent. Chem. \& Ind. p. 86.

German, R. J., Jones, A. S. \& Nadarajah (1961). Polysaccharides of Mycobacterium phlei. Nature, Lond. 189, 1008.

JEENER, H. \& JEENER, R. (1952). Cytological studies of Thermobacterium acidophilus R. 26 cultured in absence of deoxyribonucleosides or uracil. Exp. cell Res. 3, 675 .

MacNurt, W. S. (1952). The enzymically catalysed transfer of the deoxyribosyl group from one purine and pyrimidine to another. Biochem. J. 50, 384.

MARKHAM, R. \& SMrth, J. D. (1951). Chromatographic studies of nucleic acids. 4. The nucleic acid of the turnip yellow mosaic virus, including a note on the nucleic acid of the tomato bushy stunt virus. Biochem. J. 49, 401 .

MARSHAK, A. \& VogeL, H. J. (1951). Microdetermination of purines and pyrimidines in biological materials. J. biol. Chem. 189, 597.

MickLe, H. (1948). Tissue disintegrator. J. roy. Micr. Soc. 68, 10.

O'Kane, B. G. (1954). Non-lipoic pyruvate systems: acetate formation by Proteus and acetyl phosphate formation by Clostridium. Fed. Proc. 13, 739.

Palmstierna, H. (1956). Glycogen-like polyglucose in $E$. coli-B during the first hours of growth. Acta chem. scand. 10, 567.

REICHent, R. (1944). Determination of the total lipid of natural substances. Helv. chim. Acta, 27, 961.

SchLAMOWITZ, M. (1951). On the nature of rabbit liver glycogen II. Iodine absorption spectra. J. biol. Chem. 190, 519. 
Stein, E. A. \& Fischer, E. H. (1960). Bacillus subtilis, $\alpha$-amylase a zinc protein complex. Biochim. biophys. Acta, 39, 287.

Strange, R. E. (1956). The structure of an amino sugar present in certain spores and bacterial cell walls. Biochem. $J$. 64, 23 P.

Waring, W. S. \& Werkman, C. H. (1944). Iron deficiency in bacterial metabolism. Arch. Biochem. 4, 75.

WEBLEY, D. M. (1954). The morphology of Nocardia opaca Waksman and Henrici (Proactinomyces opacus) Jensen when grown on hydrocarbons, vegetable oils, fatty acids and related substances. J. gen. Microbiol. 11, 420.

WEBLEY, D. M. (1960). The effect of deficiency of iron, zinc and manganese on the growth and morphology of Nocardia opaca. J. gen. Microbiol. 23, 87.

Work, E. (1957). Biochemistry of the bacterial cell wall. Nature, Lond. 179, 841.

Wyatт, G. R. (1951). The purine and pyrimidine composition of deoxypentose nucleic acids. Biochem. J. 48, 584 . 